\title{
Temporal changes in the amino acid contents of particulate organic matter sedimenting in the Bay of Banyuls-sur-Mer (northwestern Mediterranean)
}

\author{
L. Medernach, A. Grémare* ${ }^{*}$ J. M. Amouroux, J. C. Colomines, G. Vétion \\ Observatoire Océanologique de Banyuls, UMR CNRS No. 7621, BP 44, 66651 Banyuls-sur-Mer Cedex, France
}

\begin{abstract}
We monitored gross sedimentation rates (GSR) together with organic carbon, total hydrolysable (THAA) and enzymatically available (EHAA) amino acid contents of the particulate organic matter collected within 2 sediment traps moored during a $4 \mathrm{yr}$ period at a shallow station $(18 \mathrm{~m})$ in the Bay of Banyuls-sur-Mer (northwestern Mediterranean). GSRs were between 0.26 and $470.55 \mathrm{~g} \mathrm{DW} \mathrm{m}^{-2} \mathrm{~d}^{-1}$ They were low during spring and summer, and usually higher but much more variable during fall and winter. Organic carbon concentrations were between 1.21 and $6.94 \%$ DW, versus 3.36 and $29.16 \mathrm{mg} \mathrm{g}^{-1} \mathrm{DW}$, and 0.54 and $14.44 \mathrm{mg} \mathrm{g}^{-1} \mathrm{DW}$ for THAA and EHAA, respectively. EHAA/THAA ratios were between 13.91 and $65.78 \%$. These 4 parameters showed an annual periodicity and correlated negatively with GSR, which supports the role of resuspension in controlling sedimentation. THAA and EHAA spectra were both dominated by glycine, aspartic acid, glutamic acid and alanine. However, there were consistent differences between the 2 kinds of spectra. EHAAs were enriched in threonine, glutamic acid, leucine and aspartic acid; and depleted in arginine, lysine, glycine and histidine. EHAA spectra showed fewer temporal changes than THAA spectra. In all cases but one, significant changes in THAA spectra were related to glycine, aspartic acid, glutamic acid and threonine, and were indicative of the presence of degraded material, probably due to resuspension. We computed degradation indexes based on both THAA and EHAA spectra. THAA degradation index was between -0.318 and 1.363 versus 0.051 and 1.006 for EHAA. Both of these indexes showed an annual periodicity and correlated positively (although weakly) with EHAA/THAA ratios. None of them correlated negatively with GSR. This last result suggests that EHAA/THAA ratios constitute a better index of the lability of particulate organic matter than degradation indexes.
\end{abstract}

KEY WORDS: Particulate organic matter - Amino acids - Bioavailability - Temporal changes · Resuspension

\section{INTRODUCTION}

The organic material available to benthic organisms inhabiting the coastal zone is highly heterogeneous. This heterogeneity refers both to the origin of particulate organic matter (POM) and to its degradation state. These 2 factors affect the nutritional value of POM (i.e., its true availability to benthic organisms).

*Corresponding author. E-mail: gremare@obs-banyuls.fr
Differences in nutritional values may be empirically derived from bioassays involving either demographic (Cheng et al. 1993), growth (Marsh et al. 1989, Grémare et al. 1997) or absorption experiments (Charles et al. 1995). Such an approach however only results in relative estimates of POM quality and must thus be repeated for any given environment and/or period of time. Previous examinations have tried to identify biochemical descriptors of POM nutritional values (Tenore 1983, Grémare et al. 1988, 1997, Grémare 1994). This particular field of research is based on 2 
main concepts: digestibility and nutritional requirements. An important proportion of the sedimentary POM corresponds to refractory forms that cannot be absorbed by benthic organisms because of the characteristics of their digestive systems (Plante \& Jumars 1992, Plante \& Shriver 1998). It thus seems essential to assess the particular fraction of POM which is indeed available to benthic fauna in order to describe the interactions between these 2 compartments. This is not an easy task, since the importance of this bioavailable fraction is dependent on the heterotroph feeding on POM (Mayer et al. 1997). A possible approach consists in mimicking digestion using either weak acid (Tenore 1981, 1983) or enzymatic (Mayer et al. 1986, 1995, Lan \& Pan 1993) hydrolysis. Its validity has been recently supported by the use of regression models linking available protein rations and growth rates in the bivalve Abra ovata (Grémare et al. 1997). Based on the comparison between the biochemical composition of benthic primary consumers and their primary food sources, Phillips (1984) suggested that benthic detritivores may be limited by the availability of specific micronutrients (such as essential amino and fatty acids) rather than by bulk nutrients (such as carbon and nitrogen). This hypothesis was later supported by the analysis of population dynamics of opportunistic surface deposit-feeders in Chesapeake Bay (Marsh \& Tenore 1990).

A sound biochemical approach aimed at assessing the nutritional value of POM must thus account for its digestibility and its capacity to meet the nutritional requirements of benthic fauna. One satisfactory attempt is the biomimetic, kineticbased approach proposed by Mayer et al. (1995) for the quantification of enzymatically hydrolyzable amino acids (EHAA) in marine sediments. With this approach, digestion is mimicked through incubation in the presence of a non-autohydrolyzable enzyme, whereas potential limitations by nitrogenous compounds are assessed through the quantification of individual essential amino acids using high performance liquid chromatography (HPLC).

Field surveys assessing the EHAA contents of marine sediments are still relatively scarce. Moreover, such studies have often considered stations that were only sampled once (Dauwe \& Middelburg 1998, Dauwe et al. 1999a,b). Therefore, no sound information is currently available on either the kinetics or the possible causes of short-term tempo- ral changes in amino acid concentrations and spectra. During the present study, we tackled this problem by monitoring changes in both total hydrolyzable amino acid (THAA) and EHAA concentrations of sedimenting POM, collected weekly and during a 4 yr period within 2 sediment traps moored in the Bay of Banyuls-surMer.

\section{MATERIALS AND METHODS}

Sediment trap. Two sediment traps were deployed between June 1992 and May 1996 at an 18 m deep station $\left(42^{\circ} 29^{\prime} 082^{\prime \prime} \mathrm{N}, 03^{\circ} 08^{\prime} 421^{\prime \prime} \mathrm{E}\right)$ in the Bay of Banyuls-sur-Mer (northwestern Mediterranean) (Fig. 1). Traps consisted of polyethylene pipes prolonged by a cone and a collector. The inner diameter of the pipe was $40 \mathrm{~cm}$, with a total height of $190 \mathrm{~cm}$, giving an aspect ratio of 4.75 . The mouths of the traps were located $3 \mathrm{~m}$ above the sediment surface.

Biochemical assays. The contents of the traps were collected weekly by SCUBA diving. They were taken to the laboratory where they were centrifuged (4000 rpm, $15 \mathrm{~min}$ ), frozen, briefly rinsed with distilled water, freeze-dried and weighed. Gross sedimentation rates (GSRs) were defined as the total amount of material sampled in a sediment trap with a known crosssectional area over a known length of time. Biochemi-

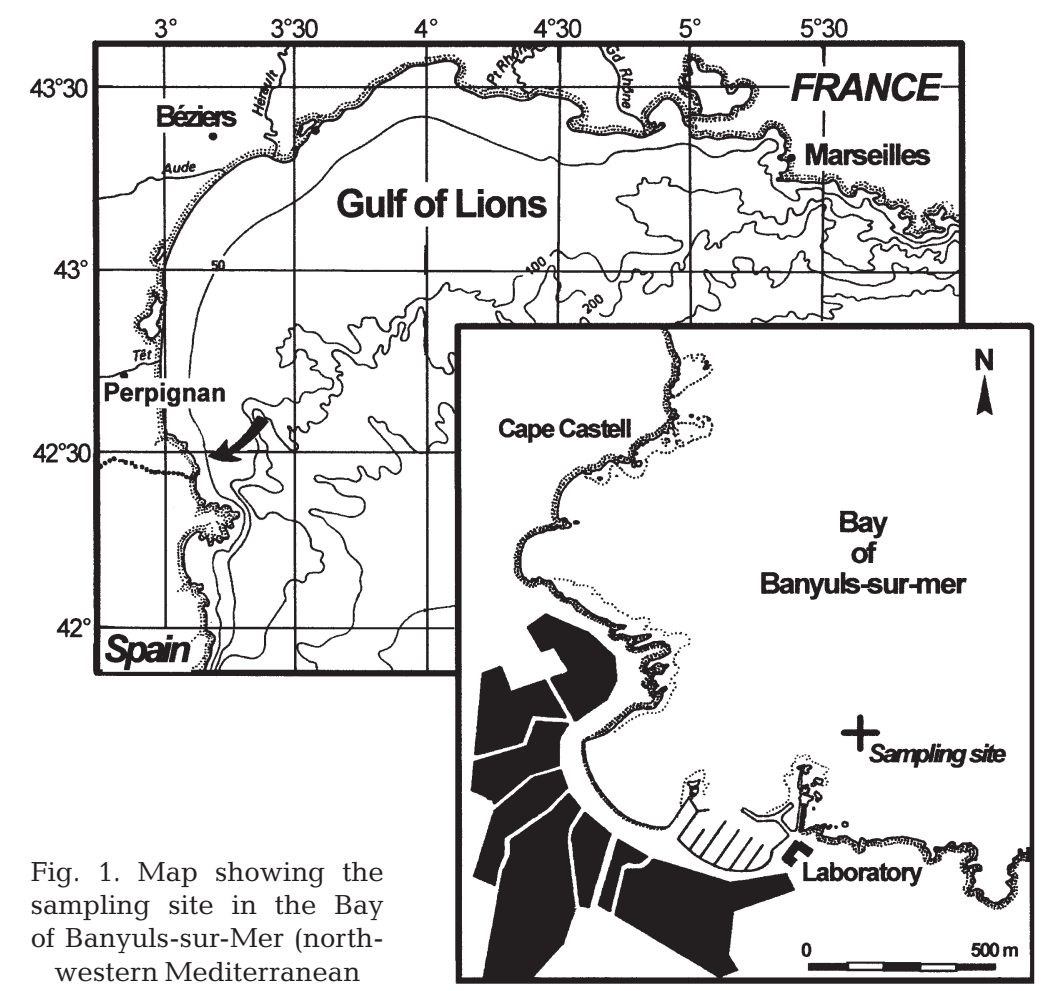


cal analyses were run every other week on the material which passed through a $200 \mu \mathrm{m}$ mesh. This fraction was stored at $-20^{\circ} \mathrm{C}$ prior to analysis.

Organic carbon contents were measured after acidification (1 N HCl) using a CHN Perkin Elmer 2400 analyzer.

Sediment (15 mg DW) was submitted to a strong acid hydrolysis $\left(500 \mu \mathrm{l}\right.$ of $6 \mathrm{~N} \mathrm{HCl}, 100^{\circ} \mathrm{C}, 24 \mathrm{~h}$, under vacuum). Subsamples $(0.4 \mathrm{ml})$ of the hydrolyzates were neutralized with $0.4 \mathrm{ml}$ of $6 \mathrm{~N} \mathrm{Na} \mathrm{OH}$ and buffered with $0.8 \mathrm{ml}$ of $\mathrm{H}_{3} \mathrm{BO}_{3}(0.4 \mathrm{M}$, pH 8). Fluorescent derivatives were obtained by adding $6 \mu \mathrm{l}$ of an orthophtaldialdehyde solution (125 $\mathrm{mg}$ in $2.5 \mathrm{ml}$ of methanol and $0.125 \mathrm{ml}$ of mercaptoethanol) and $400 \mu \mathrm{l}$ of $\mathrm{H}_{3} \mathrm{BO}_{3}$ to $100 \mu \mathrm{l}$ of those samples. THAA identification was based on retention times within an HPLC column (Lindroth \& Mopper 1979) and achieved through comparison with a standard containing 19 amino acids. THAA quantification was based on fluorescence measurements (excitation wavelength: $335 \mathrm{~nm}$, emission wavelength: $450 \mathrm{~nm}$ ). Homoserine and s-methyl cysteine were both used as internal standards.

EHAAs were extracted following the biomimetic approach proposed by Mayer et al. (1995); 100 mg DW of sediment was poisoned with $1 \mathrm{ml}$ of a solution containing 2 inhibitors of bacterial active transport systems (0.1 M sodium arsenate and $0.1 \mathrm{mM}$ pentachlorophenol within a $\mathrm{pH} 8$ sodium phosphate buffer). This mixture was allowed to incubate for $1 \mathrm{~h}$. Then, $100 \mu$ l of Proteinase $\mathrm{K}$ solution $\left(1 \mathrm{mg} \mathrm{ml}^{-1}\right)$ was added, and the samples incubated for $6 \mathrm{~h}$ at $37^{\circ} \mathrm{C}$. Samples were centrifuged to discard remaining particulate material. Then, $75 \mu$ l of pure TCA was added to $750 \mu \mathrm{l}$ of supernatant to precipitate macromolecules, which are considered to be non-suitable for absorption. Of the supernatant $750 \mu \mathrm{l}$ was then hydrolyzed and processed as described for THAA. In addition, a blank accounting for possible degradation of the enzyme was carried out.

Both THAA and EHAA assays were run in triplicate. For both fractions, we computed the degradation index proposed by Dauwe et al. (1999a). This index is based on a principal component analysis (PCA) carried out on THAA spectra measured for several kinds of POM differing by their lability. Its computation consists of a correction and a summation of the factors' coefficients for each amino acid along the first axis (i.e., the one reflecting most degradation) of this PCA. Methionine was not included in these calculations due to detection problems.

Meteorological data. Meteorological data (wind speed and direction, precipitation, state of the sea) covering the entire study period were purchased at the Cape Béar 'Météo-France' station.
Statistics. The existence of periodicity was checked using harmonical analysis for GSR, organic carbon, THAA and EHAA concentrations, EHAA/THAA ratio, and degradation indexes (Grémare et al. 1997). Interannual differences were checked using Kruskal-Wallis non-parametric ANOVAs. Due to strong seasonal heterogeneity, these ANOVAs were performed independently for the 2 main periods (see below) defined by GSR characteristics (Grémare et al. 1997). The relationships between GSR and organic carbon, THAA and EHAA concentrations were assessed using log-log regression models (Grémare et al. 1997, 1998). The relationship between THAA and EHAA degradation indexes was assessed using a simple linear regression model. The same procedure was used to assess the relationship between THAA and EHAA degradation indexes and GSR. Amino acid spectra were classified using cluster analyses (Euclidean distance, average group method) based on percent contribution to the total data set. Two analyses were run independently for THAA and EHAA spectra. A third one was based on both types of spectra. THAA and EHAA spectra were also directly compared using $\chi^{2}$ tests. All these statistical procedures were carried out using either Statistica ${ }^{\circledR}$ or Statgraphics ${ }^{\circledR}$ software.

\section{RESULTS}

\section{GSR}

Sediment traps were recovered 200 times during the study period. Temporal changes of GSR are presented in Fig. 2. GSRs were between 0.26 (4 to 11 April 1995) and $470.55 \mathrm{~g} \mathrm{DW} \mathrm{m}^{-2} \mathrm{~d}^{-1}$ (19 December 1995). The harmonical analysis showed the existence of an annual cycle (apparent period of $52 \mathrm{wk}$, data not shown). Within each of the 4 studied years, it was possible to distinguish 2 different periods by looking at GSRs. The first one was characterized by relatively low and constant GSRs, and more or less corresponded to spring and summer. The second one was characterized by relatively high and highly variable GSRs, and mostly corresponded to fall and winter. The duration of the period characterized by high GSR varied between 14 and 27 wk during the $4 \mathrm{yr}$ of our study. The average GSRs recorded during fall and winter significantly differed from year to year (Kruskal-Wallis ANOVA; p < 0.001); they were between 21.93 (1994 to 1995) and $108.30 \mathrm{~g} \mathrm{DW} \mathrm{m}^{-2} \mathrm{~d}^{-1}$ (1995 to 1996). The average GSRs recorded during spring and summer (overall mean of $9.47 \mathrm{~g} \mathrm{DW} \mathrm{m}^{-2} \mathrm{~d}^{-1}$ ) did not significantly differ from year to year (Kruskal-Wallis ANOVA; $\mathrm{p}=0.540$ ).

Organic carbon. Temporal changes in organic carbon concentrations are also shown in Fig. 2. Organic 


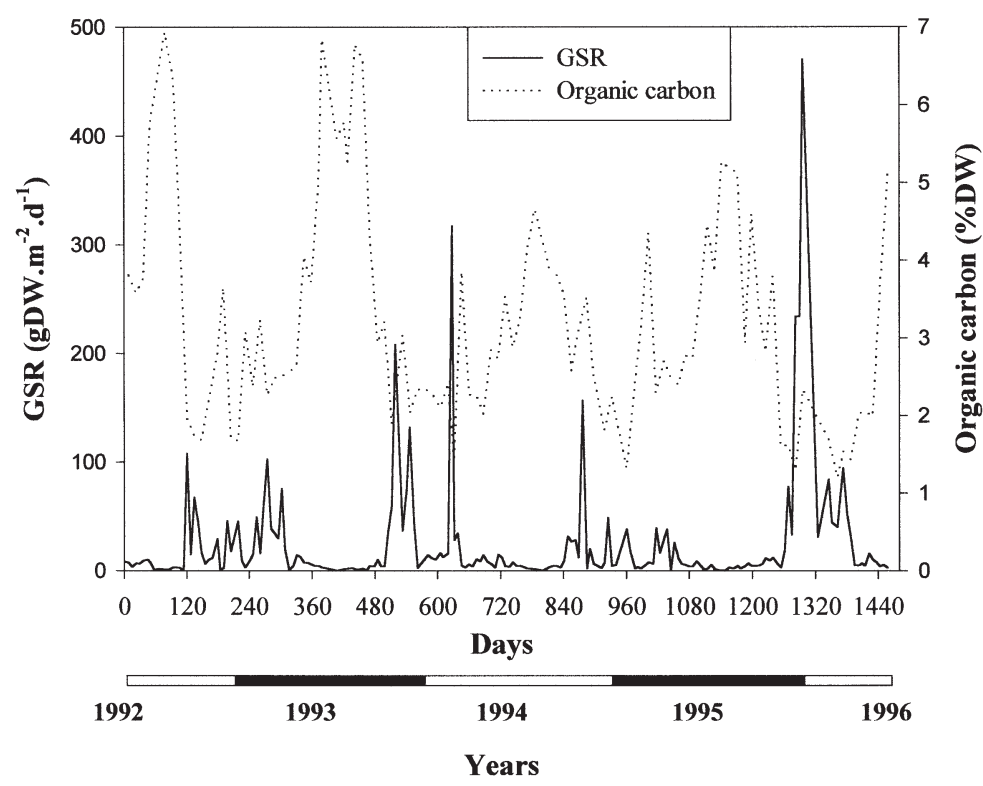

Fig. 2. Temporal changes of GSRs (gross sedimentation rates) and organic carbon concentrations

carbon contents were between 1.21 (12 to 23 February $1996)$ and $6.94 \%$ DW (12 to 18 August 1992); they followed an annual cycle (apparent period of $52 \mathrm{wk}$, data not shown) and correlated negatively with GSR ( $\mathrm{N}=$ $99, \mathrm{r}=0.484, \mathrm{p}<0.001)$. Organic contents were usually higher during spring and summer than during fall and winter. The average organic contents recorded during spring and summer significantly differed from year to year (Kruskal-Wallis ANOVA; $\mathrm{p}=0.017$ ); they were between 3.63 (1995) and 5.01\% DW (1993). The average organic contents recorded during fall and winter differed among years as well (Kruskal-Wallis ANOVA; $\mathrm{p}=0.005)$; they were between 1.59 (1995 to 1996) and 2.66 (1994 to 1995).

\section{THAA and EHAA}

Temporal changes in THAA concentrations are shown in Fig. 3A. THAA concentrations were between 3.36 (12 to 23 February 1996) and $29.16 \mathrm{mg} \mathrm{g}^{-1} \mathrm{DW}$ (24 August to 1 September 1993). They followed an annual cycle (main period of $52 \mathrm{wk}$, data not shown) and correlated negatively with GSR $(\mathrm{N}=99, \mathrm{r}=0.719, \mathrm{p}<$ 0.001). THAA concentrations were thus usually higher during spring and summer than during fall and winter. We nevertheless observed a peak in THAA concentrations in late winter during both $1994\left(19.71 \mathrm{mg} \mathrm{g}^{-1} \mathrm{DW}\right.$, 1 to 8 March) and 1995 (23.67 $\mathrm{mg} \mathrm{g}^{-1}$ DW, 21 to 28 February). The average THAA concentrations recorded during fall and winter significantly differed from year to year (Kruskal-Wallis ANOVA; $\mathrm{p}<0.001$ ); they were be- tween 4.50 (1995 to 1996) and $11.51 \mathrm{mg} \mathrm{g}^{-1}$ DW (1994 to 1995). The average THAA concentrations recorded during spring and summer (overall mean of $16.36 \mathrm{mg} \mathrm{g}^{-1} \mathrm{DW}$ ) did not significantly differ from year to year (Kruskal-Wallis ANOVA; $p=0.329$ ). When expressed in terms of organic carbon, THAA concentrations were between 0.17 (13 to 19 December 1995) and $0.54 \mathrm{mg} \mathrm{AA} \mathrm{mg}^{-1} \mathrm{C}$ (21 to 28 February 1995). They showed a principal period of $104 \mathrm{wk}$ and a secondary one of $52 \mathrm{wk}$, which reflects the existence of a yearly periodicity (data not shown).

Temporal changes in EHAA concentrations are also shown in Fig. 3A. EHAA concentrations were between 0.54 (12 to 19 December 1995) and $14.44 \mathrm{mg} \mathrm{g}^{-1} \mathrm{DW}$ (24 August to 1 September 1993). The harmonical analysis showed the existence of a yearly cycle (apparent period of $52 \mathrm{wk}$, data not shown). EHAA concentrations correlated negatively with GSR $(\mathrm{N}=88, \mathrm{r}=0.709, \mathrm{p}<$ $0.001)$ and positively with THAA $(\mathrm{N}=88, \mathrm{r}=$ $0.899, \mathrm{p}<0.001)$. They were thus generally higher during spring and summer than during fall and winter. During the late winter of 1994 and 1995, 2 peaks of EHAA concentrations (9.96 and $12.40 \mathrm{mg} \mathrm{g}^{-1}$ DW) were nevertheless observed during the 2 sampling periods also associated with high THAA concentrations (i.e., 1 to 8 March 1994 and 21 to 28 February 1995). The average EHAA concentrations recorded during fall and winter significantly differed from year to year (Kruskal-Wallis ANOVA $; \mathrm{p}<0.001$ ). They were reasonably close during the first $3 \mathrm{yr}$ of the survey (between 2.40 and $4.74 \mathrm{mg} \mathrm{g}^{-1} \mathrm{DW}$ ) but much lower (0.89 $\left.\mathrm{mg} \mathrm{g}^{-1} \mathrm{DW}\right)$ during 1995 and 1996. In contrast to GSR and THAA, the average EHAA recorded during spring and summer significantly differed from year to year (Kruskal-Wallis ANOVA; $\mathrm{p}=0.022$ ); it was between 5.30 (1994) and $8.56 \mathrm{mg} \mathrm{g}^{-1} \mathrm{DW}$ (1993).

Temporal changes of the EHAA/THAA ratio are shown in Fig. 3B. During the period under study, this ratio was between 13.91 (13 to 19 December 1995) and $65.78 \%$ (9 to 16 March 1993). EHAA/THAA ratio correlated negatively with GSR $(\mathrm{N}=88, \mathrm{r}=0.378, \mathrm{p}<$ 0.001). It seemed to decrease between 1993 and 1995. The ordinate associated to the annual frequency thus constituted only a secondary maximum in the corresponding periodogram (data not shown). The highest values of the EHAA/THAA ratio were usually recorded during spring and summer. There were significant differences from year to year between the average values of the EHAA/THAA ratios recorded during spring and summer and during fall and winter (Kruskal-Wallis ANOVAs; $\mathrm{p}<0.001$ in both cases). 


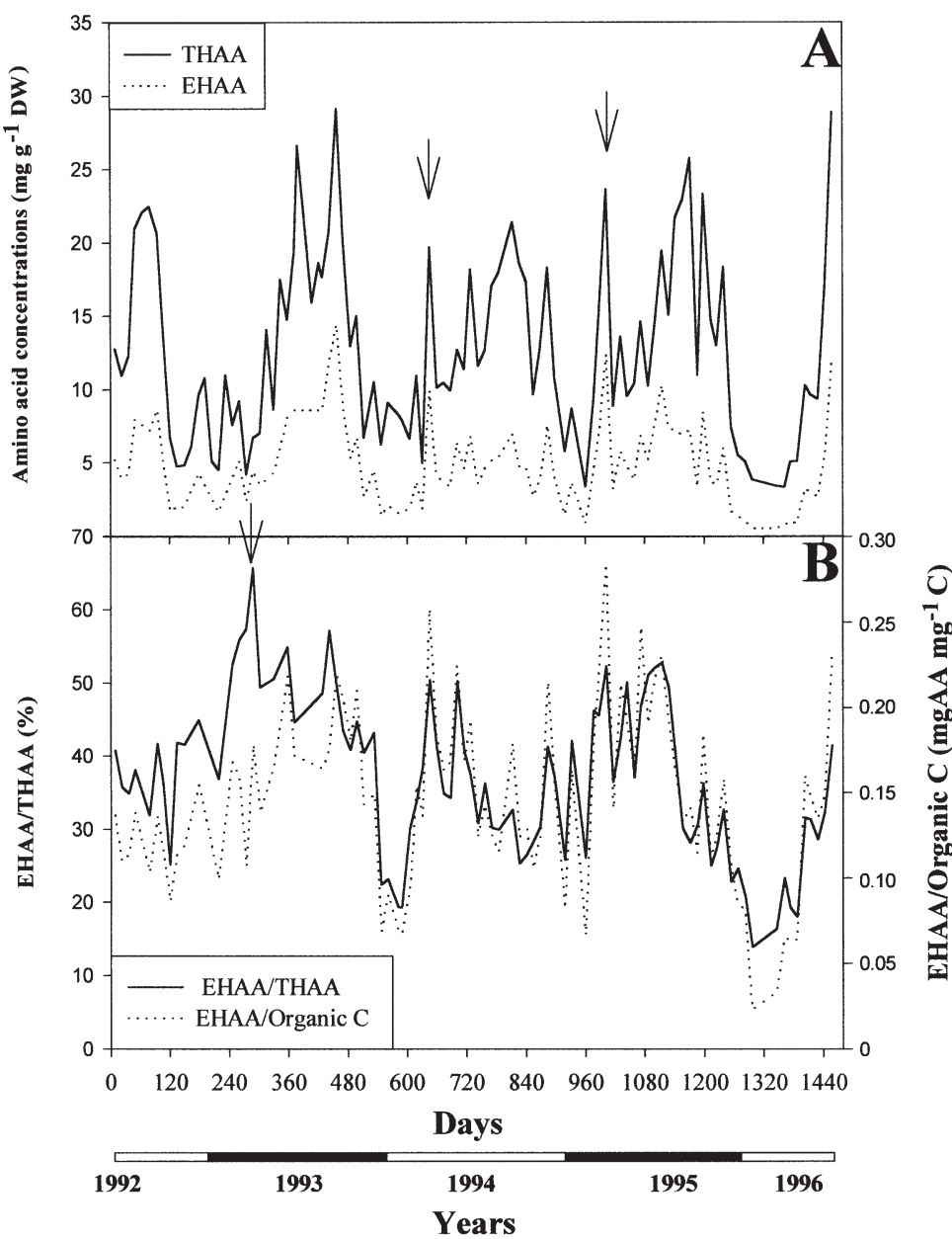

Fig. 3. Temporal changes in (A) THAA and EHAA concentrations based on dry weight, and (B) EHAA concentrations based on organic carbon and EHAA/THAA ratios. Arrows indicate the 3 sampling periods presumably corresponding to the sedimentation of the late-winter/earlyspring phytoplanktonic bloom (see 'Results: THAA and EHAA' for details). (AA: amino acids)

When expressed in terms of organic carbon, EHAA concentrations were between 0.02 (13 to 19 December 1995) and $0.28 \mathrm{mg} \mathrm{AA} \mathrm{mg} \mathrm{C}^{-1}$ (21 to 28 February 1995) (Fig. 3B). Those concentrations correlated positively with EHAA/THAA ratios $(\mathrm{N}=88, \mathrm{r}=0.768, \mathrm{p}<0.001)$. The harmonical analysis carried out on EHAA concentrations based on organic carbon showed the existence of a yearly periodicity (main period of $52 \mathrm{wk}$, data not shown).

\section{THAA spectra}

The relative contributions of each amino acid to the THAA fraction are shown in Fig. 4A. On average, glycine, aspartic acid, glutamic acid and alanine con- tributed 15.6, 12.7, 11.6 and $10.0 \%$ of the total, respectively. Serine, leucine, valine, threonine, arginine and lysine contributions were between 5 and $10 \%$, whereas phenylalanine, isoleucine, tyrosine, histidine and taurine contributed $<5 \%$ of the total. The corresponding variation coefficients were maximal for the 3 least represented amino acids, namely taurine $(84.0 \%)$, histidine $(47.7 \%)$ and tyrosine $(40.8 \%)$. The results of the cluster analysis based on THAA spectra are shown in Fig. 5. The spectra of 11 sampling periods seemed to differ from the general pattern (distance linkage <6\%). The 4 THAA spectra corresponding to the material collected between 7 November and 19 December 1995 all presented high contributions of glycine. The THAA spectra of the material collected between 10 and 17 August 1993, 7 and 14 September 1993, 23 and 30 November 1993, 1 and 10 February 1994, 18 and 22 February 1994, and 20 April and 3 May 1994 were all characterized by low contributions of aspartic and glutamic acids. The THAA spectrum of the material collected between 9 and 16 March 1993 presented high contributions of aspartic and glutamic acids and a lower contribution of threonine. We examined the weather conditions during these 11 sampling periods. The results (not shown) suggest that in most cases (i.e., 7 out of 11) those periods were associated with strong winds and/or rough sea conditions.

In spite of the low linkage distances between the different sampling periods forming the main group, it is interesting to notice that sampling periods were not randomly distributed within this group. Successive sampling periods instead tended to group together, which led to the formation of time series in the different subgroups. This trend is especially clear for the samples quoted 1-8, 17-19, 91-94, 82-86, 95-97, $9-12,43-51,55-58,72-81$, and $28-41$ in Fig. 5. The distinction between successive time series often coincided with the transition between the 2 different periods defined based on the characteristics of GSR (see above). Some of the sampling periods belonging to the 1995 and 1996 spring/summer periods (quoted 82-86 and 95-97 in Fig. 5) grouped together. These observations suggest the existence of slight changes in the THAA spectra in relation with: (1) the existence of 2 different periods characterized by 2 different sedimentation regimes during each year, and (2) between year variability. 

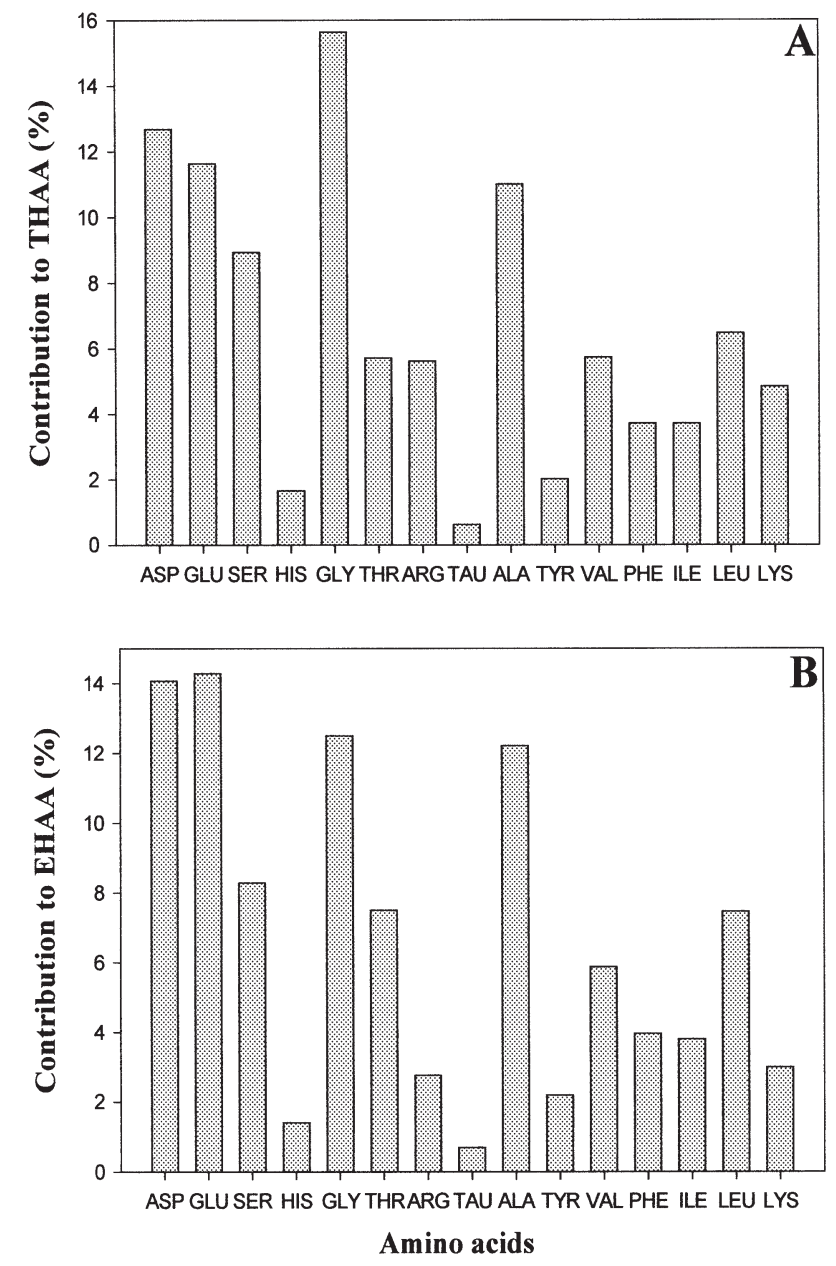

Fig. 4. Average (A) THAA and (B) EHAA spectra

\section{EHAA spectra}

The average contributions of each amino acid to the EHAA fraction are shown in Fig. 4B. Glutamic acid, aspartic acid, glycine and alanine contributed respectively to $14.3,14.1,12.5$ and $12.2 \%$ of the total. Serine, leucine, valine and threonine contributions were between 5 and $10 \%$, whereas arginine, lysine, phenylalanine, isoleucine, tyrosine, histidine and taurine contributed $<5 \%$. As for THAA, the corresponding variation coefficients were maximal for 3 of the least represented amino acids (taurine: $78.6 \%$, histidine: $31.1 \%$, lysine: $42.3 \%$ ). The results of the cluster analysis based on EHAA spectra are shown in Fig. 6. The maximal linkage distance between sampling periods was only $7.8 \%$. Only 1 spectrum (material collected between 21 and 29 May 1996) differed from the main group formed by all the other sampling periods. This material presented high contributions of glycine and alanine. The grouping of successive sampling periods was less clear than for THAA.

\section{Comparison between THAA and EHAA spectra}

The cluster analysis based on both THAA and EHAA spectra (data not shown) confirmed that 11 THAA spectra clearly differed from all the other spectra. EHAA and THAA spectra formed 2 distinct subgroups within the main group of spectra. Arginine, lysine, glycine and histidine contributions were lower for EHAA than for THAA. By opposition threonine, glutamic acid, leucine and aspartic acid contributions were higher for EHAA than for THAA. It should be stressed that differences between the THAA and EHAA spectra usually remained low. $\chi^{2}$ tests carried out for each sampling period indeed showed significant differences for only 9 sampling periods. Five of them (23 to 30 November 1993, 26 April to 3 May 1994, 14 to 21 November 1995, 21 to 28 November 1995, 13 to 19 December 1995) also presented THAA spectra differing from the main group (see above). The 4 other sampling periods (21 to 28 June 1994, 13 to 20 December 1994, 7 to 13 February 1995, and 8 to 14 March 1995) were characterized by a much lower contribution of tyrosine to THAA than to EHAA.

\section{Degradation indexes}

Temporal changes in THAA and EHAA degradation indexes are presented in Fig. 7. The THAA degradation index was between -0.318 (20 to 27 October 1992) and 1.363 (23 February to 2 March 1993) versus 0.051 (25 July to 1 August 1995) and 1.006 (10 to 17 August 1993) for the EHAA degradation index. There was a significant $(\mathrm{N}=88, \mathrm{r}=0.230, \mathrm{p}=0.031)$ correlation between both of these indexes. The values of the degradation indexes corresponding to the THAA and the EHAA fractions were close when the THAA degradation index was high. When the THAA degradation index was low, the degradation index computed based on the EHAA fraction was higher. Neither THAA nor EHAA degradation indexes correlated significantly with GSR $(\mathrm{N}=99, \mathrm{r}=0.100, \mathrm{p}=$ 0.315 ; and $\mathrm{N}=88, \mathrm{r}=0.010, \mathrm{p}=0.715$; for THAA and EHAA, respectively), but both correlated positively with EHAA/THAA ratio $(\mathrm{N}=88, \mathrm{r}=0.283, \mathrm{p}=0.022$; and $\mathrm{N}=$ 88, $\mathrm{r}=0.518, \mathrm{p}<0.001$; for THAA and EHAA, respectively) and showed a yearly periodicity (data not shown).

\section{DISCUSSION}

\section{Temporal changes in THAA and EHAA concentrations}

We already reported on temporal changes in the biochemical characteristics (organic matter, carbohydrates, lipids, total proteins and THAA) of the material 


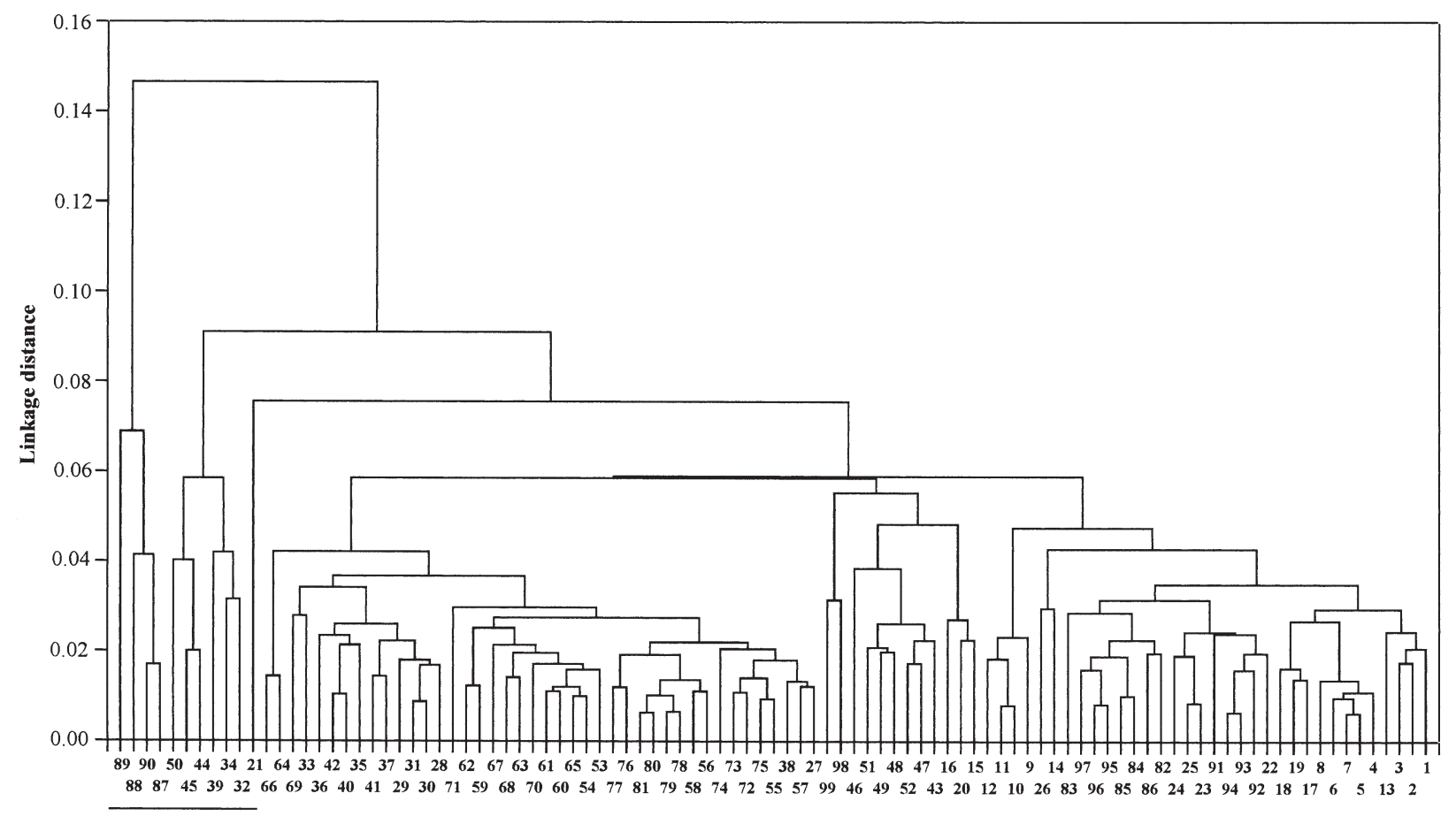

Code for sampling periods

Fig. 5. Results of the cluster analysis based on the THAA spectra. Numbers (from 1 to 99) refer to the rank of sampling periods. The horizontal bar below codes regroups the 11 sampling periods differing from the main group formed by all the other sampling periods (see 'Results: THAA spectra' for details)

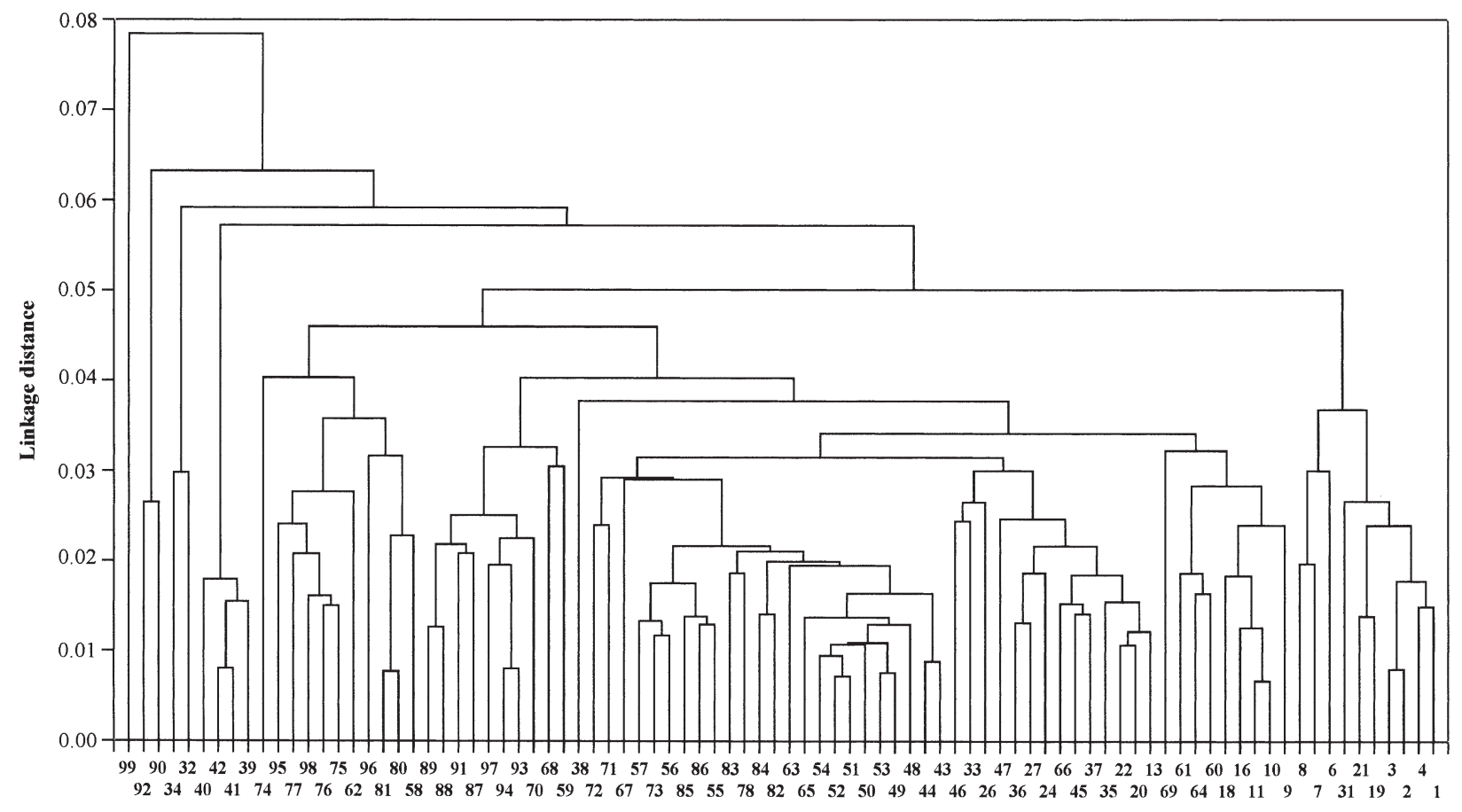

Code for sampling periods

Fig. 6. Results of the cluster analysis based on the EHAA spectra (see Fig. 5 for the sampling period code) 


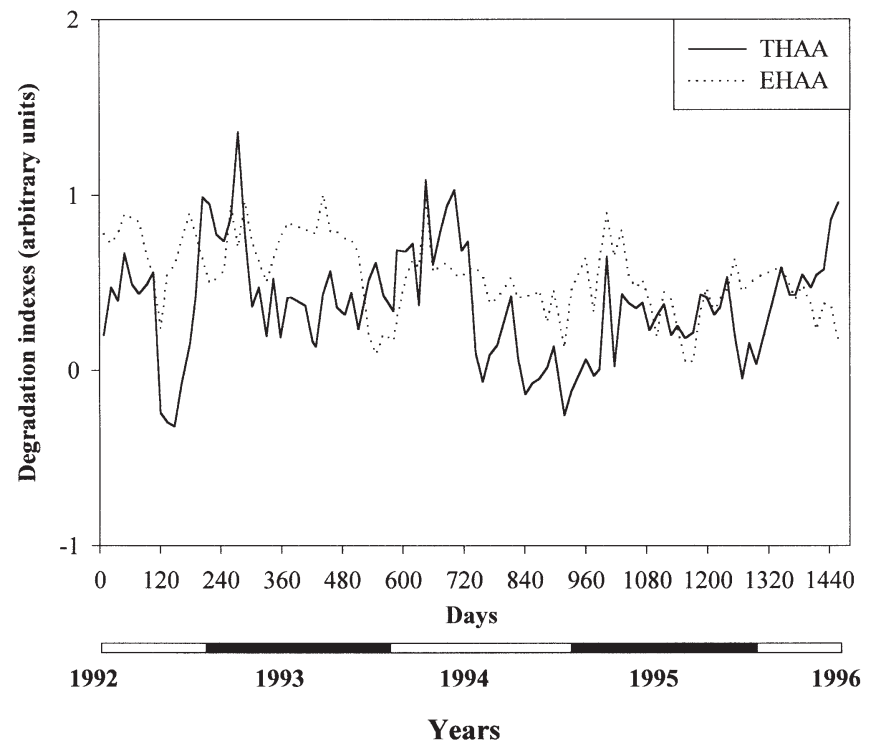

Fig. 7. Temporal changes in THAA and EHAA degradation indexes

sedimenting in the Bay of Banyuls-sur-Mer in conjunction with meteorological data (Grémare et al. 1997, 1998). We found a negative correlation with GSRs for all the biochemical parameters that were assayed. In agreement with Buscail (1991), we interpreted these results as indicative of the occurrence of 2 main sources for the material collected within the sediment traps: (1) POM sedimenting directly from the water column (which is characterized by a high nutritional value and by high concentrations of the assayed biochemical compounds), and (2) POM resulting from the resuspension of sediments (which is characterized by a lower nutritional value and low concentrations of the assayed biochemical compounds). In this context, seasonality mostly results from changes in the hydrodynamic regime, with a much higher frequency of easterly storms (inducing strong resuspension events) during the fall/winter than during the spring/summer period. The data collected during the present study are in good agreement with this pattern because of: (1) the yearly periodicity of changes in THAA concentrations, EHAA concentrations and EHAA/THAA ratios, (2) the negative relationship between GSRs and both THAA and EHAA concentrations, and (3) the negative relationship between GSRs and EHAA/THAA ratios.

In the western Mediterranean, the most important event in terms of pelagic productivity is constituted by the late-winter/early-spring diatom bloom, which occurs between late January and April, and lasts for less than a month (Jacques 1970). We believe that some of our results show the consequences of this bloom on the biochemical characteristics of the sedimenting POM through the observation of peaks in either both THAA and EHAA concentrations (1 to 8 March 1994 and 21 to 28 February 1995) or EHAA/ THAA ratios (9 to 16 March 1993). A typical annual cycle regarding both the quantity and the biochemical composition of POM sedimenting in the Bay of Banyuls-sur-Mer can thus be considered as composed of the succession between 2 long periods differing in their meteorological characteristics, and by an important but more punctual primary production event.

\section{Temporal changes in THAA spectra}

The results of the cluster analysis based on THAA spectra showed their relative constancy throughout the period under study. Distance linkages between sampling periods were always low. Glycine, aspartic acid, glutamic acid and alanine were the most abundant amino acids, which is consistent with results reported for sediment trap materials collected in other areas (Compiano \& Romano 1988, Faganeli 1989, Cowie \& Hedges 1992, Sigleo \& Schulz 1993).

Our results are also consistent with the existence of a constant trend in THAA spectra in relation to degradation (Dauwe \& Middelburg 1998, Dauwe et al. 1999a). According to these authors, increasing concentrations of arginine, aspartic acid and glycine are consistently associated with more degraded POM. The status of threonine is less clear, with a decrease of its contribution during degradation according to Dauwe \& Middelburg (1998), but an increase according to Dauwe et al. (1999a). The preferential accumulation of glycine during degradation is consistent with our own observations for the samples collected between 7 November and 15 December 1995. Glycine tends to accumulate during degradation because of its association to structural material, and because it constitutes a degradation product of more complex amino acids (Macko \& Estep 1983, cited by Sigleo \& Shultz 1993). Increased contributions of glycine to THAA spectra were always related to strong hydrodynamism.

For some other sampling periods, differences in THAA spectra mostly consisted in reduced contributions of aspartic and glutamic acids. High concentrations of these 2 amino acids are generally considered as indicative of fresh POM, since both tend to be transformed in non-protein amino acids during degradation (Lee \& Cronin 1982, 1984, Dauwe \& Middelburg 1998). The decreasing contribution of aspartic acid during degradation remains, however, in slight contradiction with the results reported by Dauwe \& Middelburg (1998) and then by Dauwe et al. (1999a). In contrast to what was observed for the increase of glycine, it was not always possible to link the decrease of aspartic and glutamic acids to strong hydrodynamism. The sam- 
pling periods before 14 September 1993 and 3 May 1994 were calm, resulting in low GSRs (4.55 and $6.56 \mathrm{~g}$ DW $\mathrm{m}^{-2} \mathrm{~d}^{-1}$, respectively). The cause of the sampling of degraded material within the sediment traps on these 2 dates is thus still open to question.

The analysis of the THAA spectrum of the POM collected between 9 and 16 March 1993 led to different conclusions relative to the degradation level of the collected material. The contributions of aspartic and glutamic acids were higher than average, whereas the contributions of both threonine and arginine were lower. The increase of aspartic and glutamic acids seems to indicate the presence of fresh POM (see above). This is supported by the decrease of arginine and threonine (Dauwe et al. 1999a) (but see the restriction for threonine above). The presence of fresh material is also supported by the fact that the highest EHAA/THAA ratio of the whole study was recorded during this sampling period.

In conclusion, 10 of the 11 THAA spectra that differed most from the average spectrum were indicative of the sampling of more degraded POM, whereas a single one suggested the presence of fresher POM. In most cases, the sampling of degraded POM could be linked to strong hydrodynamism and thus resuspension. By opposition, the THAA spectra of the 2 sampling periods supposedly corresponding to spring bloom sedimentation (i.e., 1 to 8 March 1994 and 21 to 28 February 1995) did not significantly differ from the average spectrum, and the material collected between 9 and 16 March 1993 was the only instance for which the THAA spectrum indicates the sampling of fresher material. These results confirm that degradation probably constitutes the most important process in driving changes in THAA spectra. The data also support the role of resuspension in controlling gross sedimentation in the Bay of Banyuls-sur-Mer (Charles et al. 1995, Grémare et al. 1997, 1998).

\section{Temporal changes in EHAA spectra}

The results of the cluster analysis based on EHAA spectra show fewer temporal changes than for THAAs. This finding has important consequences for the use of EHAA in view of assessing the nutritional value of sedimentary POM. As stated above, nutritional values reflect both digestibility and limitation by either specific or bulk nutriments. Since EHAA spectra are almost constant, it is then possible to assess the concentration of each amino acid in a given sample based on the measure of the sum of the concentrations of all amino acids within this sample. This last parameter can be measured using spectrofluorometry instead of HPLC, which reduces both the length and the cost of the analyses (Mayer et al. 1995). Our results suggest that digestibility might be the most important factor controlling the nutritional value of sedimenting POM (at least for nitrogenous compounds) and thus that it may not be necessary to assess each (essential) amino acid separately. In this sense our data support the use of spectrofluorometric assays in future studies, provided their sensitivity is high enough (Grémare unpubl. data).

The average contributions of essential EHAA recorded during the present study can be compared with those in a composite marine invertebrate (Phillips 1984 ) to infer potential limitations (Dauwe et al. 1999b). This shows that the 2 basic amino acids arginine and histidine are the most deficient within the sedimenting POM relative to benthic invertebrate tissues. Similar comparisons have already been carried out by Dauwe et al. (1999b) for 3 types of sediment in the North Sea. Lysine appeared to be most deficient during our study. However, this result should be treated with some caution due to the low contribution of this amino acid, which results in high variability (Colomines pers. obs.). Our data show that phenylalanine is also deficient but to a lower extent, which was also found by Dauwe et al. (1999b). These results support the good correlation between basic and aromatic amino acids and: (1) growth rates in the deposit-feeding polychaete Capitella sp. I (Marsh et al. 1989), and (2) digestibility of protein food sources in shrimps (Lan \& Pan 1993). It would now be interesting to assess simultaneously the essential EHAA composition of both sedimentary POM and benthic invertebrates within the same environment, to better assess the influence of the synthetic composition given by Phillips (1984) on the identification of deficiency in arginine, histidine and phenylalanine.

\section{Comparison between EHAA and THAA spectra}

Dauwe et al. (1999b) reported major and consistent differences in the THAA and EHAA spectra of sedimentary POM. The existence of such differences is confirmed by the separation of THAA and EHAA spectra in the cluster analysis involving both of these spectra. The nature of the differences recorded during the present study is in good agreement with the results of Dauwe et al. (1999b) as well. These authors reported an increase of the contributions of aspartic acid, glutamic acid and threonine, and a decrease of the contributions of glycine, arginine and histidine within the EHAA fraction. They also reported similar contributions in both the THAA and the EHAA fractions for alanine, serine and valine. All these observations were confirmed by our own results. The slight differences 
between the results of our 2 studies involve: (1) the lack of increase in the contribution of isoleucine and phenylalanine within the EHAA fraction, and (2) the lack of decrease of the contributions of tyrosine within the EHAA fraction.

The comparison of temporal changes in THAA and EHAA degradation indexes shows: (1) a lower range of variation for EHAA, and (2) larger differences between fractions when POM is more degraded. The first of these 2 observations reflects the greater constancy of the EHAA spectra (see above). The second one confirms the existence of larger differences between EHAA and THAA spectra for sedimentary organic matter than for source materials (Dauwe et al. 1999b). This suggests that differences between EHAA and THAA spectra result more from a modification of the THAA spectra in relation with degradation than from the cleavage pattern of Proteinase K (Mayer et al. 1995).

\section{Indexes of POM lability}

The EHAA/THAA ratio is one of the biochemical indexes which has been proposed to infer the lability of POM (Mayer et al. 1995, Dauwe et al. 1999b). During the present study this ratio was between 13.91 and $65.78 \%$. This range is comparable with the 14 to $50 \%$ reported by Dauwe et al. (1999b) for the sediments at 5 stations located along the main transit of biogenic particles during their degradation in the North Sea. According to these authors, EHAA/THAA ratios close to $14 \%$ are characteristic of areas where degradation processes are predominant, whereas ratios close to $50 \%$ are indicative of productive area. The coincidence between the lowest EHAA/THAA ratios between the present study and the work by Dauwe et al. (1999b) supports the occasional sampling of sedimentary POM within the sediment traps deployed during the present study. The differences between our maximal values may be due to the fact that we have assayed sediment trap materials, which are usually less refractory than sediments. Materials collected within the sediment traps are also less integrative with respect to time than sediments. In this sense, it should be pointed out that both the magnitude and the sharpness of the temporal changes recorded during the present study would have probably been much lower in sedimentary POM (Grémare et al. 1997). Simultaneous surveys of temporal changes both within sediment trap materials and sedimentary POM associated to different sediment types are now required to unravel this question. The negative correlation between GSR and EHAA/THAA ratio is also consistent with the postulated role of resuspension in controlling sedimentation in the Bay of Banyuls-sur-Mer (see above).
THAA degradation indexes were between -0.318 and 1.363. Caution should be taken when comparing these results with those of Dauwe et al. (1999a) (THAA degradation index ranging from -0.35 to 1.01 for North Sea sediments) because methionine was excluded from the computation of our degradation index. Nevertheless, there seems to be good agreement between those 2 ranges, which confirms the succession of periods during which the POM collected within the sediment traps is mostly sedimentary or directly resulting from production processes. To our knowledge, this was the first time that degradation indexes were computed based on EHAA spectra. The range of this index (i.e., 0.051 to 1.006) was much lower than that for THAA. The occurrence of a higher minimal value for the EHAA degradation index was not surprising, but the existence of a lower maximum was. Along the same line, the average values of the degradation indexes were relatively close both for THAA (0.384) and EHAA (0.534). In fact, the only periods during which THAA degradation indexes were consistently lower than EHAA degradation indexes were those when THAA degradation indexes were low. Both degradation indexes correlated positively with EHAA/ THAA ratios. Surprisingly, this correlation was better for EHAA than for THAA. These results suggest that EHAA spectra are also consistently (although weakly) affected by changes in POM lability. The data also support the concept of a degradation index proposed by Dauwe \& Middelburg (1988) and Dauwe et al. (1999a). There are, however, clear restrictions in the practical use of this index due to: (1) the weakness of its positive correlation with the EHAA/THAA ratio, and (2) the absence of negative correlation with GSRs. Based on our results, it thus seems more suitable to use the EHAA/THAA ratio as an index of POM lability and to restrict the use of the degradation index proposed by Dauwe et al. (1999a) to those surveys where only THAA data are available.

There is recurrent difficulty in relating POM lability and its true availability to benthic organisms (Dauwe et al. 1999a,b). There have been only few attempts to couple biochemical and bioassays to identify (biochemical) descriptors of POM nutritional value (Grémare et al. 1988, 1997, Taghon \& Greene 1990). Grémare et al. (1997) nevertheless reported a strong correlation between the available protein ration and growth in the deposit-feeding bivalve Abra ovata. Because, the same enzymatic hydrolysis is used, this result indirectly supports the use of the EHAA/THAA ratio as an index of POM nutritional values. Other studies of this kind are clearly needed to establish the use of the EHAA/THAA ratio (as well as other degradation indexes) as descriptors of POM nutritional value. A complementary approach could consist in using multivariate analysis to study the relationships between biochemical characteristics of POM and the abundance of benthic fauna. 
Acknowledgements. This work was partly funded through the Programme National d'Océanographie Côtière (Chantier Golfe du Lion) and the EEC project METROMED. L.M. was supported by a doctoral fellowship of the French Ministère de l'Enseignement de la Recherche et de la Technologie. We would like to thank 1 of the 3 anonymous referees for his comments on the manuscript.

\section{LITERATURE CITED}

Buscail R (1991) Le cycle du carbone sur une marge continentale: aspects biogéochimiques du transfert de la matière organique à l'interface eau-sédiment. Thèse de Doctorat es Sciences, Université de Perpignan

Charles F, Grémare A, Amouroux JM, Baudart J (1995) A bioassay approach to temporal variation in the nutritional value of sediment trap material. J Exp Mar Biol Ecol 19: 65-81

Cheng IJ, Levinton JS, McCartney M, Martinez D, Weissburg MJ (1993) A bioassay approach to seasonal variation in the nutritional value of sediment. Mar Ecol Prog Ser 94: 275-285

Compiano AM, Romano JC (1988) Amino acids and monosaccharides in sediments in the vicinity of an urban sewer. Mar Environ Res 25:291-313

Cowie GL, Hedges JI (1992) Sources and reactivities of amino acids in a coastal marine environment. Limnol Oceanogr 37(4):703-724

Dauwe B, Middelburg JJ (1998) Amino acids and hexosamines as indicators of organic matter degradation state in North Sea sediments. Limnol Oceanogr 43:782-798

Dauwe B, Middelburg JJ, Herman PMJ, Heip CHR (1999a) Linking diagenetic alteration of amino acids and bulk organic matter reactivity. Limnol Oceanogr 44:1809-1814

Dauwe B, Middelburg JJ, Van Rijswijk P, Sinke J, Herman PMJ, Heip CHR (1999b) Enzymatically hydrolyzable amino acids in North Sea sediments and their possible implication for sediment nutritional values. J Mar Res 57:109-134

Faganeli J (1989) Sedimentation of particulate nitrogen and amino acids in shallow coastal waters (Gulf of Trieste, northern Adriatic). Mar Chem 26(1):67-80

Grémare A (1994) What describes fecundity of Capitella sp. I better: macro or micronutrient availability? Mar Biol 119: 367-374

Grémare A, Marsh AG, Tenore KR (1988) Short-term reproductive responses of Capitella capitata type I (Annelida: Polychaeta) fed on different diets. J Exp Mar Biol Ecol 123: 147-162

Grémare A, Amouroux JM, Charles F, Dinet A, Riaux-Gobin C, Baudart J, Medernach L, Bodiou JY, Vétion G, Colomines JC, Albert P (1997) Temporal changes in the biochemical composition and nutritional value of the particulate organic matter available to surface depositfeeders: a two year study. Mar Ecol Prog Ser 150:195-206

Grémare A, Amouroux JM, Charles F, Medernach L, Jordana E, Nozais C, Vétion G, Colomines JC (1998) Temporal changes in the biochemical composition of particulate organic matter sedimentation in the bay of Banyuls-surMer. Oceanol Acta 21(6):783-792

Jacques G (1970) Aspects quantitatifs du phytoplancton de la région de Banyuls-sur-Mer (Golfe du Lion). Thèse Doc-

Editorial responsibility: Kenneth Tenore (Contributing Editor), Solomons, Maryland, USA torat es Sciences Naturelles, Faculté des Sciences de Paris Lan CC, Pan BS (1993) In vitro digestibility simulating the proteolysis of feed protein in the midgut gland of grass shrimp Penaeus monodon. Aquaculture 109:59-70

Lee C, Cronin C (1982) The vertical flux of particulate nitrogen in the sea: decomposition of amino acids in the Peru upwelling area and the equatorial Atlantic. J Mar Res 40: $227-251$

Lee C, Cronin C (1984) Particulate amino acids in the sea: effects of primary productivity and biological decomposition. J Mar Res 42:1075-1097

Lindroth P, Mopper K (1979) High performance liquid chromatographic determination of subpicomole amino acids by precolumn derivatization with $o$-phtaldialdehyde. Anal Chem 51:1667-1674

Macko SA, Estep MLF (1983) Microbial alteration of stable nitrogen and carbon isotopic compositions of organic matter. In: Annual report of the director of the Geophysical Laboratory, 1982-1983. Carnegie Institution, Washington, DC, p 394-398

Marsh AG, Tenore KR (1990) The role of nutrition in regulating the population dynamics of opportunistic surface deposit-feeders in a mesohalyne community. Limnol Oceanogr 35:710-724

Marsh AG, Grémare A, Tenore KR (1989) Effect of food type and ration on growth of juvenile Capitella sp. I (Annelida: Polychaeta): macro- and micronutrients. Mar Biol 102: 519-527

Mayer LM, Schick LL, Setchell FW (1986) Measurement of protein in nearshore marine sediments. Mar Ecol Prog Ser 30:159-165

Mayer LM, Schick LL, Sawyer T, Plante CJ, Jumars PA, Self RL (1995) Bioavailable amino acids in sediments: a biomimetic, kinetic-based approach. Limnol Oceanogr 40: $511-520$

Mayer LM, Schick LL, Self RFL, Jumars PA, Findlay RH, Chen Z, Sampson S (1997) Digestive environments of benthic macroinvertebrate guts: enzymes, surfactants and dissolved organic matter. J Mar Res 55:785-812

Phillips NW (1984) Roles of different microbes and substrates as potential suppliers of specific essential nutrients to marine detritivores. Bull Mar Sci 12:33-47

Plante CJ, Jumars PA (1992) The microbial environment of marine deposit-feeder guts characterized via microelectrodes. Microb Ecol 23:257-277

Plante CJ, Shriver AG (1998) Differential lysis of sedimentary bacteria by Arenicola marina L.: examination of cell wall structure and exopolymeric capsules as correlates. J Exp Mar Biol Ecol 229:35-52

Sigleo AC, Shultz DJ (1993) Amino acid composition of suspended particles, sediment trap material, and benthic sediment in the Potomac estuary. Estuaries 16:405-415

Taghon GL, Greene RR (1990) Effects of sediment-protein concentration on feeding and growth rates of Abarenicola pacifica Healy et Wells (Polychaeta: Arenicolidae). J Exp Mar Biol Ecol 136:197-216

Tenore KR (1981) Organic nitrogen and caloric content of detritus. I. Utilization by the deposit-feeding polychaete Capitella capitata. Estuar Coast Shelf Sci 12:39-47

Tenore KR (1983) What controls the availability to animals of detritus derived from vascular plants: organic nitrogen or caloric availability? Mar Ecol Prog Ser 10:307-309

Submitted: March 14, 2000; Accepted: November 27, 2000

Proofs received from author(s): March 14, 2001 